\title{
ASEAN Languages Preparation at Higher Education Institutions in Ubon Ratchathani Province to Support the Opening of AEC
}

\author{
Yuvadee Jitgosol, Ph. D. \\ Tourism Program, Humanity Department, \\ The Faculty of Liberal Arts, Ubon Ratchathani University \\ Warinchamrap, Ubon Ratchathani 34190 Thailand \\ E-mail: yuvadeedr@gmail.com
}

\begin{abstract}
The objectives of this research are 1) to analyze English and other country members' languages competency (speaking, reading and writing) of the personnel of the higher education institutions in Ubon Ratchathaniand 2) to propose a suggestion to the Office of the Civil Service in preparing its personnel for ASEAN in term of developing English and other country members' language skills (speaking, reading and writing) by using quantitative research method. This research used the questionnaires to collect data. The sample of this study was the institute at high level at Ubon Ratchathani Province to consist of 155 instructors' Ubon Ratchathani university and, 143 instructors' Ubon Ratchathani Rajabhat university. The data analysis was computed by statistical package for the social sciences by using descriptive analysis such as frequency distribution, percentage distribution, arithmetic mean and standard deviation. The result of study were as follows:

- From analyzing of the present circumstance for preparation of ASEAN languages at high education was to prepare the most English language skill. As a result, the communication among ASEAN is the English language and prepare other ASEAN languages together for achieving maximum benefit with instructors at high education in the future.

- . The policy recommendation to the officer of the higher education commission for preparation of ASEAN languages at Ubon Ratchathani Province is going to the same direction both of Ubon Ratchathani university and Ubon Ratchathani Rajabhat university that the most preparation and development is the infrastructure such as to encourage teaching and training the ASEAN languages, to set a higher standard, to develop more professional English, to develop curriculums, to support more effective communications and information technology and to make the information center etc.

Thus, there are two universities that maintain the role of developing the working resource for the tourism industry are Ubon Ratchathani University and Ubon Ratchathani Rajabhat University. The two universities accepted the policy and singed the Agreement of eight professional fields: engineer, nurse, architect, surveyor, doctor, dentist, accountant and tourism. Moreover, they agree on the competency standard, the evaluation and the skill development to set a new standard beneficial to the launching of ASEAN language courses and to the increase of the competency of the resource, effectively leading to the acceptance of the ASEAN Mutual Recognition Arrangement (MRA).
\end{abstract}

Keywords: ASEAN languages, Higher Education Institutions, ASEAN Mutual Recognition Arrangement

\section{Introduction}

Thailand is going to become a member of the ASEAN Community, which consists of 10 countries: Indonesia, Malaysia, Philippines, Singapore, Thailand, Brunei Darussalam, Vietnam, Laos, Myanmar and Cambodia. To keep up with other member countries in certain areas, Thailand seeks to the preparation for developing its human resource, an agenda that was included in the country strategies $(2013$ - 2018) to prepare 
the governmental personnel for the changing arena and the contexts within. The spearhead institute in developing the human resource is Office of the Civil Service (OCSC), which is responsible for the Strategy 4: creating the balance and reengineering the internal process of the public sectors to achieve the most effectiveness and efficiency in using the resource (Civil Service Development Strategy).

The strategy was planned to increase the governmental personnel's skills and knowledge needed for the international communication such as speaking, reading and writing English and learning the neighbors' languages, culture, and tradition. Initially, English was selected to be the formal language of ASEAN. However, the member countries' languages have also been promoted so far to boost the communication competency among the members and to increase more chance of developing new businesses and potential works (Higher Education Development Plan No. 11, Year 2012 to 2016). For the Tourism Industry, in particular, it needs a big change to answer the expected tourists because tourism is an important source of the country's income. The forecast of the tourists visiting Thailand in the next 3 - 5 years between 2016 - 2019 is more than 20 million people (Three-year Development Plan 2016 - 2018). The province of Ubon Ratchathani borders with 2 ASEAN countries: Lao People's Democratic Republic and the Kingdom of Cambodia. The existing transportation and communications, such as trains, cars, and planes, are the significant factors favorable for the tourism. Consequently, Ubon Ratchathani rises to become one of the leading destinations of the lower Northeast of the country. In the last year alone, it saw the significant growth of tourism, investment, and business.

A statistic showed that the number of the tourists who crossed the borders to Ubon Ratchathani increased 3.82 percent from the last year with the value of 5,665 million bath (the National Statistical Office). That data suggests a significant change coming with the opening of the ASEAN; thereby, it signifies that the government universities in Ubon Ratchathani give their tourism industry personnel' skill development an importance and prepare them for the ASEAN languages, and it also increases more potential for the working resource. The two universities that maintain the role of developing the working resource for the tourism industry are Ubon Ratchathani University and Ubon Ratchathani Rajabhat University (Research and Deployment Institute). The two universities accepted the policy and singed the Agreement of eight professional fields: engineer, nurse, architect, surveyor, doctor, dentist, accountant and tourism. Also, they agree on the competency standard, the evaluation and the skill development to set a new standard beneficial to the launching of ASEAN language courses and to the increase of the competency of the resource, effectively leading to the acceptance of the ASEAN Mutual Recognition Arrangement (MRA). Consequently, the benefit will fall to 2.7 million workers who work in the tourism and hotel industry (Yuphawan Nongklapiwat, 2014).

The initial requirement for every position is inevitably the competency of English because it was chosen to be the official language. Therefore, the author has seen the importance of conducting a research to assess their preparation in developing English and other country members' languages and the direction of their preparation.

\section{The Objective of the Research}

2.1 To analyze English and other country members' languages competency (speaking, reading and writing) of the personnel of the higher education institutions in Ubon Ratchathani.

2.2 To propose a suggestion to the Office of the Civil Service in preparing its personnel for ASEAN in term of developing English and other country members' language skills (speaking, reading and writing).

\section{The Scope of the Research}

In this research, the research team chose the samples which are Ubon Ratchathani University and Ubon Ratchathani Rajabhat University 


\section{The Research Method and Methodology}

The research uses the quantitative research method by distributing questionnaires (1) to analyze the competency of the public personnel of the higher education institutions in Ubon Ratchathani Province in speaking, writing, and reading those languages in the workplaces (2) to propose a suggestion how to improve the competency of the public personnel of the higher education institutions in Ubon Ratchathani Province in speaking, writing, and reading those languages. The samples were 155 teachers from Ubon Ratchathani University and 143 teachers from Ubon Ratchathani Rajabhat University. The researchers used the descriptive statistics and a software for social sciences to generate frequency, percentage, average and standard deviation from the data collected in 1 year.

\section{The Tools Used in the Research}

The tool used in this research were questionnaires, which were developed by studying the existing documents and references, and old researches. The questionnaires contained closed-ended questions to access their preparation for the ASEAN languages in the higher institute level and open-ended questions to ask for their suggestions and opinions.

\subsection{The Research Result}

The following is the data showing the competency of the public personnel of the higher education institutions in Ubon Ratchathani

\subsection{The Profiles of the 155 Teachers From Ubon Ratchathani University}

Among the 155 teachers, 100 persons ( 64.5 percent) were female and 55 persons ( 35.5 percent) were male, and most of them (81 persons or 52.3 percent) were the teachers (aged between $31-40$ years old ) teaching science and applied science from the Faculty of Management Sciences, the Faculty of Science, the Faculty of Engineering and the Faculty of Agriculture. 55.5 percent of them have $\mathrm{PhD}, 85.8$ percent holds an academic position, 90.3 percent do not hold any an administrative position, and 37.4 percent have working experience more than 10 years.

77.4 percent of them do not involve in the language preparation; 81.9 percent learn English; 79.4 percent do not learn Lao; 97.4 percent do not learn Burmese; 79. 4 percent do not learn Cambodian; 85.2 percent do not learn Thai; 98.1 percent do not learn Filipino; 79.4 do not learn Vietnamese; 96.8 do not learn Malay; 96.8 do not learn Indonesian; 85.8 do not learn Chinese; and 78.7 do not learn Japanese.

\subsection{The Profiles of the 155 Teachers From Ubon Ratchathani Rajabhat University}

Most of them (78 persons or 54.5 percent) are the teachers from Group 3 (Applied Science, which is comprise the Faculty of Agriculture, the Faculty of Industrial Technology, the Faculty of Business and Management, the Faculty of Science, and the Faculty of Computer Science: 90 persons (or 62.9 percent) were female, and 53 persons (or 37.1 percent) were male; 57.3 percent of them are aged between 31 - 40 years old; 78.3 percent of them hold master degrees, 92.3 percent of them hold academic positions as professors; 93.7 percent of them do not hold any an administrative position; 28.7 percent of percent have working experience 4 6 years.

57.3 percent do not involve in the language preparation; 98.6 percent learn English; 83.9 percent do not learn Lao; 97.2 percent do not learn Burmese; 84.6 percent do not learn Cambodian; 79.7 percent do not learn Thai; 94.4 percent do not learn Filipino; 62.9 do not learn Vietnamese; 89.5 do not learn Malay; 94.4 percent do not learn Indonesian; 74.8 do not learn Chinese; and 86.7 do not learn Japanese. 


\subsection{The Result: The Preparation in Various Dimensions for The ASEAN Language of The Teachers From Ubon Ratchathani University}

5.4.1 Personnel: The preparation of the teachers from Ubon Ratchathani University was low (with the mean of 2.32). The mean ranged from highest to lowest: your institute provides the training and development of the ASEAN languages for the teachers (mean $2.41=$ low); your institute prepares its academic staff for the ASEAN languages (mean $2.29=\mathrm{low}$ ); your institutes prepares its supporting staff for the ASEAN languages (mean 2.35 $=$ high); and your institute supports the teachers who specialize in the ASEAN languages (mean $2.21=$ low).

5.4.2 The ASEAN Language Programs: The preparation of the teachers from Ubon Ratchathani University for the teaching programs was low (with the mean of 2.19). The mean ranged from highest to lowest: your institute promotes the ASEAN language programs (mean $2.35=10 \mathrm{w}$ ); your institute promotes the activities involving the ASEAN languages, such as ASEAN language campuses, ASEAN language contests, etc. (mean $2.27=$ low); your institute has developed ASEAN language programs for its personnel (mean $2.17=$ low); your institute have developed media for teaching the ASEAN languages (mean $2.09=$ low); and your institute support any researches that involves the ASEAN languages (mean $2.05=$ low).

\subsubsection{The Result: The Preparation in Various Dimensions For The ASEAN Language of The Teachers From Ubon Ratchathani Rajabhat University}

Personnel: the preparation of the teachers from Ubon Ratchathani Rajabhat University was high (with the mean of 2.99). The mean ranged from highest to lowest: your institute provides the training and development of the ASEAN languages for the teachers (mean $3.05=$ high); your institute prepares its academic staff for the ASEAN languages (mean $3.04=$ high); your institutes prepares its supporting staff for the ASEAN languages (mean $2.98=$ high); and your institute supports the teachers who specialize in the ASEAN languages (mean 2.90 $=$ high).

The ASEAN language Programs: the preparation of the teachers from Ubon Ratchathani Rajabhat University for the teaching programs was high (with the mean of 2.82). The mean ranged from highest to lowest: your institute promotes the ASEAN language programs (mean $2.92=$ high); your institute promotes the activities involving the ASEAN languages, such as ASEAN language campuses, ASEAN language contests, etc. (mean $2.90=$ high); your institute has developed ASEAN language programs for its personnel (mean $2.79=$ high); your institute have developed media for teaching the ASEAN languages (mean $2.76=$ high); and your institute support any researches that involves the ASEAN languages (mean $2.73=$ high).

\subsection{The Recommendation for The Higher Education Institutions in Ubon Ratchathani Province in Preparing for The ASEAN Languages in The Context of Speaking, Writing, and Reading}

- $\quad$ Encourage teaching and training the ASEAN languages and set a higher standard

- Develop more professional English and other ASEAN member's languages' courses and better evaluation tools

- Develop curriculums that include ASEAN language study and research, and support more effective communications and information technology

- Host some activities relating the ASEAN languages, such as ASEAN language campuses, contests, etc.

- Establish a team responsible for the preparation of ASEAN languages

- Follow and evaluate the preparation of ASEAN languages

- Set up the ASEAN language service center available for other departments and units

- Build a collaboration network of the ASEAN languages

- Set up an administration department for the natives who comes to join the programs 
- Encourage the academic and supporting staff to study the ASEAN languages

- Create the information center for the ASEAN languages and share the information among the members

- Support the budget for developing theirs personnel's skill, conducting researches, and developing communications tools for the ASEAN languages

- Make the information center into an intermediate that can provide news and activities of the other institutes in Ubon Ratchathani Province

\section{Conclusion}

From Mutual Recognition Arrangement (MRSs) signed by 8 academies: engineer, nurse, architect, surveyor, doctor, dentist, accountant and tourism, the education institutes have the role of teaching and training their students. However, their effort has still the lack of the effectiveness in term of not answering the current situation. The recommendation is that the institutes adjust the existing courses to meet the changing demand of the employers while stricting to the Mutual Recognition Arrangement (MRSs), which, in turn, could facilitate the move of the working resource among the ASEAN members, and increase the ability of the Thai people who want to go to work outside the country.

\section{References}

[1] ASEAN Mutual Recognition Arrangement (MRA), Available: http://investasean.asean.org/index.php/page/view/aseanfree-trade-area-agreements/view/757/newsid/868/mutual-recognition-arrangements.html. March 17, 2016.

[2] Civil Service Development Strategy 2014-2018, Available:

http://www.ocsc.go.th/ocsc/th/files/CSTI/D\%20menu/stategic/strategy\%2002.pdf? March 18, 2016.

[3] Higher Education Development Plan No.11 (2012 - 2016). Available:

http://www.mua.go.th/users/bpp/developplan/download/higher_edu_plan/PlanHEdu11_2555-2559.pdf. March 17, 2016.

[4] Mutual Recognition Arrangements: MRA, Available:

http://www.mol.go.th/sites/default/files/downloads/pdf/12._bththii_8_MRAs.pdfMarch 16, 2016.

[5] National Statistical Office. Available: http://service.nso.go.th/nso/web/statseries/statseries23.html. March 17, 2016. .

OResearch and Deployment Institute: Road Map for Professional Tourism toward Free labor, Available: http://tdri.or.th/archives/download/publication/II0020.pdf. March 16, 2016.

[6] Strategic Plan for Higher Education in Thailand to prepare the ASEAN community, 2015, Commission on Higher Education.

[7] The Department of ASEAN, Ministry of Foreign Affairs. ASEAN Mini Book, Bangkok, 2013, pp. 20-22.

[8] Three-year Development Plan (2016 - 2018) of Ubon Ratchathani Provincial Administrative Organization, Available: http://www.ubon.go.th/webdatas/articles/ArticleFile6328.pdf? March 18, 2016.

[9] Ubon Ratchathani Rajabhat University, Strategic Plan of Ubon Ratchathani Rajabhat University (2014-2018), Ubon Ratchathani Rajabhat University Council, Approval No. 7/2014, July 25, 2014.

[10] Ubon Ratchathani University, Strategic Plan for Development in Ubon Ratchathani University for 5 years (20122016), Approval No. 1/2011, January 29, 2011.

[11] Yuphawan Nongklapiwat, 2014. Preparation of Thai Labor in Tourism Industry for the ASEAN Economic Community Integration, APHEIT Journal vol. 20, No. 2 pp. 158-169. 